\title{
Modifikasi Metode Analisis Daya Hambat terhadap Proses Denaturasi Protein yang Diinduksi oleh Panas
}

\author{
Modification of the Inhibitory Concentration Analysis Method of the Heat-Induced Protein \\ Denaturation Process
}

\author{
Zaldy Rusli ${ }^{1 *)}$, Lusi Agus Setiani ${ }^{1)}$ \\ ${ }^{1)}$ Universitas Pakuan, Program Studi Farmasi, Indonesia \\ *email penulis: zaldy.rusli@unpak.ac.id
}

Received: 20/09/20; Revised: 20/10/20; Accepted: 20/10/20

\begin{abstract}
Abstrak
Sebagian besar protein akan mengalami denaturasi yang lambat pada suhu tubuh, dapat terjadi dalam waktu setengah hari atau bahkan tahun. Proses denaturasi protein dapat diinduksi oleh panas sehingga akan terjadi perubahan struktur dari protein dan mengakibatkan perubahan peran biologis dari protein tersebut yang dapat berdampak bagi kesehatan. Penelitian ini bertujuan untuk mempelajari metode yang dimodifikasi untuk digunakan dalam menganalisis daya hambat suatu bahan terhadap proses denaturasi protein yang diinduksi oleh panas. Metode yang digunakan adalah metode analisis penghambatan proses denaturasi protein secara in vitro. Protein dikondisikan pada suhu tubuh $\left(37^{\circ} \mathrm{C}\right)$ yang dilanjutkan dengan menginduksi protein menggunakan panas pada suhu $70^{\circ} \mathrm{C}$. Modifikasi dilakukan dengan menambahkan suatu kontrol tanpa perlakuan, reagen uji protein serta persamaan yang digunakan untuk menentukan konsentrasi penghambatan denaturasi 50\% protein (IC50). Analisis dilakukan dengan mengukur serapan menggunakan spektrofotometer UV-Vis. Hasil penelitian menunjukkan, bahwa konsentrasi dari natrium diklofenak dan ekstrak air daun afrika (Vernonia amygdalina) dengan menggunakan parameter IC50 diperoleh hasil berturut-turut adalah 520,80 mg/L dan 3.751,88 mg/L. Metode ini dapat digunakan untuk menentukan daya hambat proses denaturasi protein, tetapi masih memerlukan pengembangan lebih lanjut, agar diperoleh suatu metode yang memiliki tingkat akurasi dan presisi yang baik.
\end{abstract}

Kata kunci: daun Afrika; daya hambat; denaturasi protein; induksi panas; modifikasi metode; natrium diklofenak

\begin{abstract}
Most proteins denaturate slowly at body temperature, which can occur within half a day or even years, but the process of protein denaturation can be induced by heat so that there will be a change in the structure of the protein and it can cause many biological consequence. This research aims to study a modified method used in analyzing the inhibition of a material against the protein denaturation process heat-induced. The method used was the analysis of the inhibits of protein denaturation process by in vitro. Protein is conditioned at body temperature $\left(37{ }^{\circ} \mathrm{C}\right)$ followed by heat-induced at $70{ }^{\circ} \mathrm{C}$. Modification is done by adding a control without treatment, protein test reagent and the equation to determine the inhibitory concentration 50\% protein denaturation (IC50). The analysis was carried out by measuring the absorption using a UV-Vis spectrophotometer. The results showed that the concentration of diclofenac sodium and the water extract of African leaves (Vernonia amygdalina) using the IC50 parameter and the results were $520.80 \mathrm{mg} / \mathrm{L}$ and 3,751.88 $\mathrm{mg} / \mathrm{L}$. This method can be used, however, further testing and development is still needed, in order to obtain a method that has a good accuracy and precision.
\end{abstract}

Keywords: African leaves; heat-induced; inhibition concentration; modification method; protein denaturation; sodium diclofenac 


\section{PENDAHULUAN}

Setiap sel pada manusia mengandung ribuan protein berbeda, yang menjalankan berbagai fungsi biologis. Fungsi biologis dari protein dihasilkan ketika protein berada pada keadaan alaminya. Kondisi ketika protein mengalami perubahan kimia maupun biologis disebut dengan istilah denaturasi. Protein memiliki berat molekul sekitar lima ribu hingga satu juta, sehingga protein sangat mudah mengalami denaturasi (Aryadnyani $d k k ., 2020$ ).

Salah satu penyebab denaturasi protein adalah suhu. Sebagian besar protein mengalami denaturasi yang lambat pada suhu tubuh yang dapat terjadi dalam waktu setengah hari atau bahkan tahunan. Denaturasi protein dapat menyebabkan gangguan biologis seperti penyakit genetik dan kanker mutasi somatik (Fersht, 2013).

Berbagai bahan, baik bahan kimia obat maupun bahan alam, telah diteliti dan dikembangkan untuk menghambat terjadinya denaturasi protein. Bahan kimia obat yang diketahui memiliki daya hambatyang tergantung kepada dosis antara lain indometasin dan fenilbutazon (Saso $d k k$., 1999), serta banyak peneliti yang melaporkan bahwa natrium diklofenak juga memiliki daya hambat terjadinya denaturasi protein. Bahan alam seperti daun afrika (Vernonia amygdalina) diketahui memiliki aktivitas penghambatan terhadap terjadinya denaturasi protein (Alara $d k k .$, 2017).

Metode pengujian daya hambat denaturasi protein secara in vitro yang ada saat ini dan telah banyak digunakan dalam berbagai penelitian adalah mengukur tingkat kekeruhan hasil denaturasi protein yang diinduksi oleh panas menggunakan spektrofotometer UV-Vis pada panjang gelombang $660 \mathrm{~nm}$ (Bailey-shaw $d k k$., 2017; Chandra $d k k$., 2012; Heendeniya $d k k .$, 2018; Mahendran $d k k .$, 2015; Quasie $d k k .$, 2016). Namun, terdapat perbedaan persamaan yang digunakan pada penelitian yang dilakukan oleh Mahendran $d k k$. (2015) dibandingkan yang lain, sehingga menyebabkan bias dari metode tersebut. Metode tersebut juga mengasumsikan semua protein $(100 \%)$ mengalami denaturasi (Anyasor $d k k$., 2019). Hal ini bertentangan dengan hasil penelitian yang dilakukan oleh (Nikolaidis \& Moschakis, 2017).

Hal tersebut yang menjadi dasar dilakukannya penelitian ini. Penelitian ini bertujuan untuk mempelajari metode yang dimodifikasi untuk digunakan dalam menganalisis daya hambat suatu bahan obat maupun bahan alam terhadap proses denaturasi protein yang disebabkan oleh panas. Penelitian ini dilakukan dengan modifikasi metode yang telah ada, terutama dengan adanya parameter kelompok kontrol tanpa perlakuan dan parameter kontrol negatif (kelompok dengan perlakuan), sehingga dapat diperoleh laju penghambatan yang terukur.

\section{METODE PENELITIAN}

\section{Alat dan Bahan}

Penelitian ini dilakukan di laboratorium Kimia Farmasi, Program Studi Farmasi, Universitas Pakuan Bogor. Alat yang digunakan meliputi spektrofotometer UV-Vis Genesys, oven dan alat gelas laboratorium. Bahan yang digunakan meliputi daun afrika, natrium diklofenak, Tembaga sulfat, Kalium Natrium tartrat, natrium hidroksida, natrium klorida, kalium klorida, dinatrium hidrogen fosfat, kalium dihidrogen fosfat, bovine serum albumin (BSA), metanol, akuadest.

\section{Pembuatan Larutan Induk}

Penetapan daya hambat dimulai dengan pembuatan larutan buffer fosfat $\mathrm{pH}$ 
7,4, pembuatan larutan BSA $0,6 \%$, pembuatan larutan biuret, pembuatan larutan natrium diklofenak dan ekstrak air daun afrika, kemudian analisis daya hambat. Larutan buffer fosfat $\mathrm{pH} 7,4$ dibuat dengan cara melarutkan 8 gram $\mathrm{NaCl}, 200$ mg KCl, 1,44 gram $\mathrm{Na}_{2} \mathrm{HPO}_{4}$ dan $245 \mathrm{mg}$ $\mathrm{KH}_{2} \mathrm{PO}_{4}$ dalam $800 \mathrm{~mL}$ akuadest. Setelah larut, $\mathrm{pH}$ di ukur dan ditepatkan hingga $\mathrm{pH}$ 7,4 menggunakan asam fosfat atau $\mathrm{NaOH}$. Larutan BSA $0,6 \%$ dibuat dengan cara menimbang 0,6 gram BSA dan dilarutkan dalam $100 \mathrm{~mL}$ akuabidest. Larutan biuret dibuat dengan cara menimbang sebanyak 1,5 gram $\mathrm{CuSO}_{4}, 6$ gram Kalium Natrium tartrat, dicampurkan dengan $\mathrm{NaOH} 2 \mathrm{~N}$ sebanyak $375 \mathrm{~mL}$ dan dimasukan ke dalam labu ukur volume $1 \mathrm{~L}$, lalu ditambahkan akuadest hingga tanda batas.

Larutan induk natrium diklofenak dibuat dengan cara menimbang $500 \mathrm{mg}$ standar natrium diklofenak dan dilarutkan dengan $10 \mathrm{~mL}$ metanol dalam labu ukur 100 $\mathrm{mL}$, lalu diencerkan menggunakan akuadest sampai batas, sehingga diperoleh larutan induk natrium diklofenak dengan konsentrasi $5.000 \mathrm{mg} / \mathrm{L}$. Sedangkan larutan ekstrak air daun afrika dibuat dengan cara menimbang 12 gram simplisia daun afrika, kemudian direbus dalam $100 \mathrm{~mL}$ aquabidest pada suhu $90{ }^{\circ} \mathrm{C}$ selama 15 menit. Setelah didinginkan ekstrak disaring dan ditepatkan hingga $100 \mathrm{~mL}$ menggunakan akuabidest, sehingga diperoleh larutan ekstrak dengan konsentrasi $120.000 \mathrm{mg} / \mathrm{L}$.

\section{Analisis Daya hambat}

Analisis daya hambat dilakukan dengan cara mengukur serapan dari larutan uji kontrol positif (tanpa pelakuan pemanasan), kontrol negatif (dengan perlakuan pemanasan), deret larutan natrium diklofenak dan ekstrak air daun afrika. Larutan kontrol positif dibuat dengan cara mencampurkan 1,5 mL larutan BSA $0,6 \%, 1,5 \mathrm{~mL}$ larutan buffer fosfat $\mathrm{pH}$ 7,4 dan $3 \mathrm{~mL}$ biuret dengan pengulangan 3x. Serapan campuran tersebut dilakukan menggunakan spektrofotometer pada panjang gelombang maksimum yaitu 540 nm.

Larutan kontrol negatif dibuat dengan cara mencampurkan 1,5 mL larutan BSA 0,6\%, 1,5 mL larutan buffer fosfat $\mathrm{pH} 7,4$ dan $3 \mathrm{~mL}$ biuret dengan pengulangan $3 \mathrm{x}$. Campuran tersebut kemudian dipanaskan pada $37{ }^{\circ} \mathrm{C}$ selama 30 menit, lalu dipanaskan pada suhu $70{ }^{\circ} \mathrm{C}$ selama 10 menit. Setelah didinginkan, dilakukan pengukuran serapan larutan menggunakan spektrofotometer pada panjang gelombang maksimum yaitu $540 \mathrm{~nm}$. Larutan kontrol positif dan kontrol negatif dapat dilihat pada Gambar 1.



Gambar 1. [A] Larutan Kontrol Positif, [B] Larutan Kontrol Negatif

Larutan uji natrium diklofenak dibuat secara seri dengan memipet 0,$06 ; 0,12$; 0,36; 0,6 dan 1,2 mL larutan uji $5.000 \mathrm{mg} / \mathrm{L}$ ke dalam 5 buah tabung reaksi, lalu larutan dalam masing-masing tabung diencerkan menggunakan larutan buffer fosfat $\mathrm{pH} 7,4$ hingga $1,5 \mathrm{~mL}$. Ke dalam masing-masing tabung, ditambahkan 1,5 mL larutan BSA $0,6 \%$ dan $3 \mathrm{~mL}$ biuret. Campuran ini menghasilkan deret dengan konsentrasi 50, 100, 300, 500, $1000 \mathrm{mg} / \mathrm{L}$ dengan pengulangan $\quad 3 \mathrm{x}$. Masing-masing konsentrasi dipanaskan pada $37{ }^{\circ} \mathrm{C}$ selama 
30 menit, lalu dipanaskan pada suhu $70{ }^{\circ} \mathrm{C}$ selama 10 menit. Setelah didinginkan, serapan masing-masing larutan diukur menggunakan spektrofotometer pada panjang gelombang maksimum yaitu 540 nm. Larutan uji diklofenak dapat dilihat pada Gambar 2.



Gambar 2. Larutan Uji Natrium Diklofenak 50 $\mathrm{mg} / \mathrm{L}$ dan $100 \mathrm{mg} / \mathrm{L}$

Larutan uji ekstrak air daun afrika dibuat seri larutan uji dengan memipet 0,05 ; 0,$1 ; 0,2$ dan 0,25 mL larutan induk 120.000 $\mathrm{mg} / \mathrm{L}$ ke dalam 4 buah tabung reaksi, lalu larutan dalam masing-masing tabung diencerkan hingga $1,5 \mathrm{~mL}$ menggunakan larutan buffer fosfat $\mathrm{pH} 7,4$. Ke dalam masing-masing tabung, ditambahkan 1,5 mL larutan BSA $0,6 \%$ dan $3 \mathrm{~mL}$ biuret. Campuran ini menghasilkan deret dengan konsentrasi 1000, 2000, 4000, 5000 mg/L dengan pengulangan $3 \mathrm{x}$. Masing-masing konsentrasi dipanaskan pada $37^{\circ} \mathrm{C}$ selama 30 menit, lalu dipanaskan pada suhu $70{ }^{\circ} \mathrm{C}$ selama 10 menit. Setelah didinginkan, serapan masing-masing larutan diukur menggunakan spektrofotometer pada panjang gelombang maksimum yaitu 540 $\mathrm{nm}$. Larutan uji diklorofenak dapat dilihat pada Gambar 3.

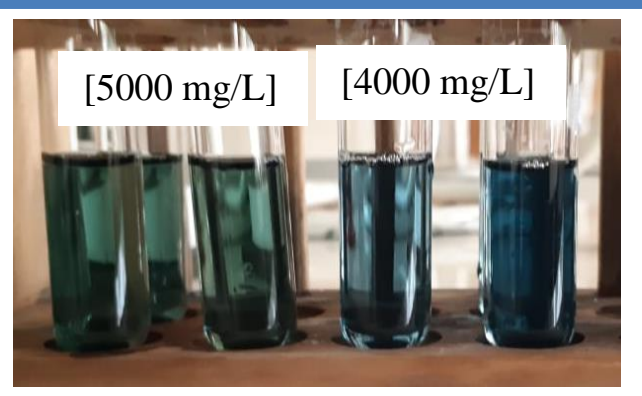

Gambar 3. Larutan Uji Ekstrak Daun Afrika $5000 \mathrm{mg} / \mathrm{L}, 4000 \mathrm{mg} / \mathrm{L}$ dan 3000 $\mathrm{mg} / \mathrm{L}$

Absorbansi yang diperoleh dirata-rata dan digunakan untuk menghitung daya hambat terhadap proses denaturasi protein menggunakan persamaan (1).

Daya hambat (IC) $=\frac{A_{u j i}-A_{\text {kontrol negatif }}}{A_{\text {kontrol positif }}-A_{\text {kontrol negatif }}} \times 100 \%$..(1)

Keterangan :

$\mathrm{A}_{\mathrm{uji}}=$ Serapan masing-masing deret larutan uji natrium diklofenak dan ekstrak air daun afrika

$A_{\text {kontrol negatif }}=$ Serapan larutan konrol negatif

$\mathrm{A}_{\text {kontrol positif }}=$ Serapan larutan kontrol positif

Selanjutnya digambarkan grafik hubungan antara konsentrasi (sumbu $\mathrm{x}$ ) dengan daya hambat (sumbu y), lalu ditentukan persamaan regresi liniernya. Persamaan regresi linier digunakan untuk menghitung konsentrasi yang dapat menghambat terdenaturasinya $50 \%$ protein (IC50) dengan menggunakan persamaan (2).

$\operatorname{IC50}(\mathrm{x})=\frac{50(\mathrm{y})-\operatorname{intercept}(\mathrm{a})}{\text { slope }(\mathrm{b})}$

\section{HASIL DAN PEMBAHASAN}

Penelitian ini merupakan studi awal dalam memperoleh suatu metode in vitro yang dapat digunakan untuk memprediksi kemampuan suatu bahan, baik bahan kimia maupun bahan alam, dalam menghambat terdenaturasinya protein. Pengujian daya hambatdenaturasi protein dilakukan menggunakan metode uji penghambatan denaturasi protein yang dilakukan oleh Chandra $d k k$. (2012), metode ini digunakan 
secara umum untuk menganalisis kemampuan penghambatan denaturasi protein.

Perbedaan modifikasi metode dan metode sebelumnya terletak pada persamaan yang digunakan. Persamaan yang digunakan pada penelitian sebelumnya adalah

$\%$ inhibition $=100 \times\left(\frac{\mathrm{V}_{\mathrm{t}}}{\mathrm{V}_{\mathrm{c}}}-1\right)$

$\mathrm{V}_{\mathrm{t}}=$ absorbansi larutan uji

$\mathrm{V}_{\mathrm{c}}=$ absorbansi larutan kontrol

Persamaan (3) dapat diturunkan lebih lanjut, menjadi persamaan (4).

$\%$ inhibition $=100 \times\left(\frac{\mathrm{V}_{\mathrm{t}}-\mathrm{V}_{\mathrm{c}}}{\mathrm{V}_{\mathrm{c}}}\right)$

Persamaan (4) menggunakan asumsi jumlah protein terdegradasi adalah $100 \%$, sehingga tidak dapat menggambarkan jumlah protein yang terdenaturasi maupun yang tidak mengalami denaturasi. Jumlah protein terdenaturasi dapat diperoleh dengan cara menghitung selisih antara jumlah protein awal (tanpa perlakuan induksi panas) dengan jumlah protein akhir setelah diinduksi oleh panas. Persamaan (1) diperoleh dari penurunan Persamaan (4) dengan menggunakan jumlah protein yang terdenaturasi sebagai pembanding.

Prinsip pembacaan pada metode sebelumnya adalah berdasarkan kekeruhan, hal ini dapat mempengaruhi pengamatan. Menurut Guo dkk. (2012) protein yang mengalami denaturasi akan terurai (unfolding) dan jika didinginkan maka protein tersebut dapat kembali ke bentuk semula (folding). Penggunaan reagen biuret dimaksudkan agar dapat membedakan antara protein yang terdenaturasi dan yang tidak terdenaturasi. Reagen ini dapat berikatan dengan protein pada ikatan peptida dan dapat bekerja dalam range yang lebar, yaitu 0,1 - 0,5 g/L (Bianchi-Bosisio,
2005). Untuk dapat mengetahui jumlah protein yang terdenaturasi, maka jumlah protein mula-mula sebaiknya tinggi (Schön $d k k ., 2017)$, sehingga masih ada sisa protein dalam jumlah yang cukup setelah mengalami denaturasi.

Hasil pengukuran absorbansi deret larutan uji natrium diklofenak dapat dilihat pada Tabel 1. Plot antara konsentrasi dan daya hambat diperoleh nilai intercept sebesar -3,7111, slope sebesar 0,1031 dan $\mathrm{R}^{2}$ sebesar 0,9994 yang dapat dilihat pada Gambar 4. Nilai IC50 diperoleh dari persamaan (2). Dengan menggunakan metode yang telah dimodifikasi, diketahui bahwa daya hambat $50 \%$ protein yang terdenaturasi (IC50) dari natrium diklofenak adalah sebesar 520,80 mg/L. Daya hambat ini disebabkan oleh kemampuan natrium diklofenak dalam berikatan dengan albumin (Hossain $d k k$., 2016) dan membuat protein lebih stabil, sehingga ketika diinduksi oleh panas, protein tidak mengalami denaturasi. Obatobat golongan Non-steroidal antiinflammatory drugs (NSAIDs) seperti natrium diklofenak telah terbukti mengikat serum albumin pada residu triptofan (Czub $d k k ., 2020)$.

Metode ini juga dapat digunakan untuk mengukur daya hambat dari ekstrak bahan alam. Ekstrak yang digunakan dalam penelitian ini adalah ekstrak air daun afrika. Hasil pengukuran daya hambat terhadap denaturasi protein oleh daun afrika dapat dilihat pada Tabel 1. Plot antara konsentrasi dan daya hambat diperoleh nilai intercept sebesar -12,1162, slope sebesar 0,0166 dan $\mathrm{R}^{2}$ sebesar 0,9726 yang dapat dilihat pada Gambar 5. Nilai IC50 diperoleh dari persamaan 2. Hasil penelitian menunjukkan bahwa ekstrak air daun afrika memiliki daya hambat $50 \%$ denaturasi protein (IC50) pada konsentrasi $3.751,88 \mathrm{mg} / \mathrm{L}$. Aktivitas 
penghambatan ini disebabkan oleh adanya metabolisme sekunder seperti senyawa flavonoid (Kumar dkk., 2011) yang berikatan dengan albumin dan membuat protein lebih stabil, sehingga ketika diinduksi oleh panas, protein tidak mengalami denaturasi. Hal ini disebabkan adanya interaksi antara gugus hidroksil dan cincin aromatik senyawa flavonoid dengan residu asam amino dalam rantai protein (Zinellu $d k k .$, 2015).

Tabel 1. Daya Hambat Larutan Natrium Diklofenak dan Ekstrak Air Daun Afrika

\begin{tabular}{ccccc}
\hline Larutan Uji & $\begin{array}{c}\text { Konsentrasi } \\
(\mathbf{m g} / \mathbf{L})\end{array}$ & Absorbansi & $\begin{array}{c}\text { Daya Hambat } \\
(\mathbf{\%})\end{array}$ & $\begin{array}{c}\text { IC50 } \\
(\mathbf{m g} / \mathbf{L})\end{array}$ \\
\hline & Kontrol (+) & 0,313 & & \\
& Kontrol (-) & 0,263 & & \\
Natrium & 50 & 0,264 & 0,67 & \\
Diklofenak & 100 & 0,266 & 6,04 & 520,80 \\
& 300 & 0,277 & 28,19 & \\
& 500 & 0,288 & 48,99 & \\
& 1000 & 0,312 & 98,66 & \\
Ekstrak Air & Kontrol (+) & 0,206 & & \\
Daun Afrika & Kontrol (-) & 0,125 & & \\
& 1000 & 0,127 & 1,66 & \\
& 2000 & 0,147 & 26,56 & \\
& 4000 & 0,164 & 48,55 & \\
\hline
\end{tabular}

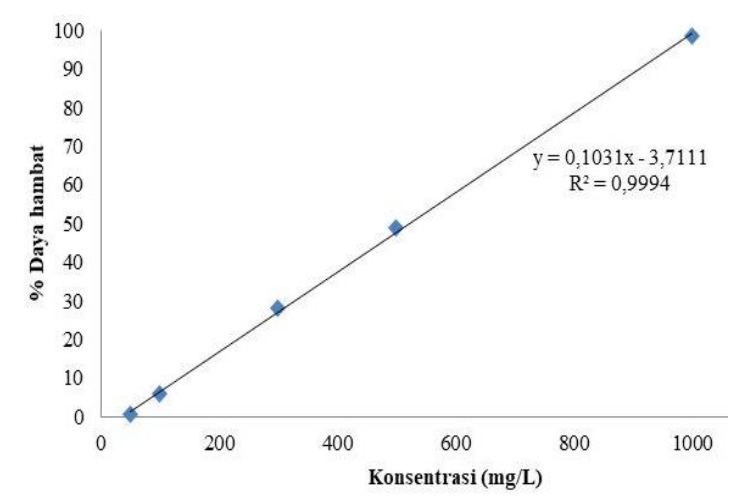

Gambar 4. Grafik Hubungan Konsentrasi dan Daya Hambat dari Natrium Diklofenak

Metode ini masih memerlukan studi dan pengembangan lebih lanjut, terutama untuk mengetahui mekanisme penghambatan terjadinya denaturasi protein. Metode ini juga masih memerlukan verifikasi lebih lanjut agar metode ini

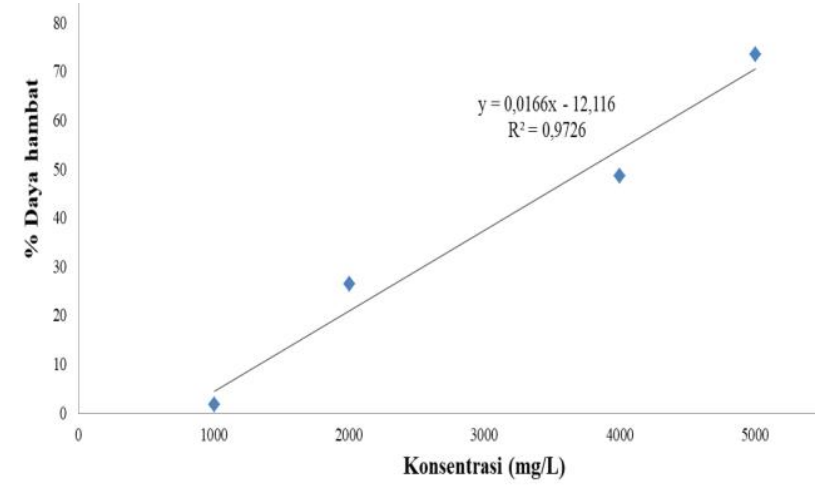

Gambar 5. Grafik Hubungan Konsentrasi dan Daya Hambat dari Ekstrak Air Daun Afrika

memiliki tingkat akurasi dan presisi yang baik. Metode ini juga perlu dilakukan pengujian menggunakan serum albumin pada manusia. 


\section{KESIMPULAN}

Metode yang telah dimodifikasi ini dapat digunakan dalam menentukan daya hambat senyawa obat maupun bahan alam. Konsentrasi yang dapat menghambat terdenaturasinya $50 \%$ protein (IC50) dari natrium diklofenak menggunakan metode ini adalah 520,80 mg/L dan ekstrak air daun afrika adalah 3.751,88 mg/L. Metode ini masih memerlukan pengembangan lebih lanjut, agar diperoleh suatu metode yang memiliki tingkat akurasi dan presisi yang baik.

\section{UCAPAN TERIMA KASIH}

Penelitian ini didanai oleh Deputi Bidang Penguatan Riset dan Pengembangan KEMENRISTEK/BRIN melalui hibah Penelitian Dosen Pemula Perguruan Tinggi 2020.

\section{DAFTAR RUJUKAN}

Alara, O. R., Abdurahman, N. H., Mudalip, S. K. A., \& Olalere, O. A. (2017). PHYTOCHEMICAL AND PHARMACOLOGICAL

PROPERTIES OF Vernonia amygdalina: A REVIEW. Journal of Chemical Engineering and Industrial Biotechnology, 2, 80-96. https://doi.org/10.15282/jceib.v2i1.38 71

Anyasor, G. N., Okanlawon, A. A., \& Ogunbiyi, B. (2019). Evaluation of anti-inflammatory activity of Justicia secunda Vahl leaf extract using in vitro and in vivo inflammation models. Clinical Phytoscience, 5(1). https://doi.org/10.1186/s40816-0190137-8

Aryadnyani, N. P., Chairlan, \& Inderiati, D. (2020). Pengaruh Suhu dan Waktu Pemanasan Terhadap Ketahanan Telur Ascaris lumbricoides. Meditory: The Journal of Medical Laboratory, 8(6), 40-45.

https://doi.org/https://doi.org/10.3399 2/m.v8i1.1113

Bailey-shaw, Y. A., Williams, L. A. D., Green, C. E., Rodney, S., \& Smith, A. M. (2017). In-Vitro Evaluation of the Anti-Inflammatory Potential of Selected Jamaican Plant Extracts using the Bovine Serum Albumin Protein Denaturation Assay. International Journal of Pharmaceutical Sciences Review and Research, 47(1), 145-153. Bianchi-Bosisio, A. (2005). PROTEINS | Physiological Samples. In P. Worsfold, A. Townshend, \& C. B. T.E. of A. S. (Second E. Poole (Eds.), Encyclopedia of Analytical Science (pp. 357-375). Elsevier. https://doi.org/https://doi.org/10.1016/ B0-12-369397-7/00494-5

Chandra, S., Chatterjee, P., Dey, P., \& Bhattacharya, S. (2012). Evaluation of in vitro anti-inflammatory activity of coffee against the denaturation of protein. Asian Pacific Journal of Tropical Biomedicine, 2(1), S178S180. https://doi.org/10.1016/S22211691(12)60154-3

Czub, M. P., Handing, K. B., Venkataramany, B. S., Cooper, D. R., Shabalin, I. G., \& Minor, W. (2020). Albumin-Based Transport of Nonsteroidal Anti-Inflammatory Drugs in Mammalian Blood Plasma. Journal of Medicinal Chemistry, 63(13), 6847-6862. https://doi.org/10.1021/acs.jmedchem. 0c00225

Fersht, A. R. (2013). Denaturation (Proteins). In Brenner's Encyclopedia of Genetics: Second Edition (Vol. 2). Elsevier Inc. https://doi.org/10.1016/B978-0-12374984-0.00393-4

Guo, M., Xu, Y., \& Gruebele, M. (2012). Temperature dependence of protein folding kinetics in living cells. Proceedings of the National Academy of Sciences of the United States of America, 109(44), 17863-17867. https://doi.org/10.1073/pnas.1201797 109 
Heendeniya, S. N., Ratnasooriya, W. D., \& Pathirana, R. N. (2018). In vitro investigation of anti-inflammatory activity and evaluation of phytochemical profile of Syzygium caryophyllatum. Journal of Pharmacognosy and Phytochemistry, $7(1)$, 1759-1763. http://www.phytojournal.com/archive s/2018/vol7issue1/PartX/7-1-93533.pdf

Hossain, M. K., Khatun, A., Rahman, M., Akter, M. N., Chowdhury, S. A., \& Alam, S. M. (2016). Characterization of the Effect of Drug-Drug Interaction on Protein Binding in Concurrent Administration of Sulfamethoxazol and Diclofenac Sodium Using Bovine Serum Albumin. Advanced Pharmaceutical Bulletin, 6(4), 589595. https://doi.org/10.15171/apb.2016.073

Kumar, A., Ghosh, S., \& Vaishali. (2011). An experimental evaluation of Ageratum conyzoides on membrane stabilization and protein denaturation during acute inflammation and arthritis. Biomedical and Pharmacology Journal, 4(2), 313317. https://doi.org/10.13005/bpj/302

Mahendran, G., Manoj, M., Rajendra Prasad, K. J., \& Narmatha Bai, V. (2015). Antioxidants, antiproliferative, anti-inflammatory, antidiabetic and anti-microbial effects of isolated compounds from Swertia corymbosa (Grieb.)Wight ex C.B. Clark - An in vitro approach. Food Science and Human Wellness, 4(4), 169-179.

https://doi.org/10.1016/j.fshw.2015.08 .003

Nikolaidis, A., \& Moschakis, T. (2017). Studying the denaturation of bovine serum albumin by a novel approach of difference-UV analysis. Food Chemistry, 215(August), 235-244. https://doi.org/10.1016/j.foodchem.20 16.07.133
Quasie, O., Zhang, Y. M., Zhang, H. J., Luo, J., \& Kong, L. Y. (2016). Four new steroid saponins with highly oxidized side chains from the leaves of Vernonia amygdalina. Phytochemistry Letters, 15, 16-20. https://doi.org/10.1016/j.phytol.2015. 11.002

Saso, L., Valentini, G., Casini, M. L., Mattei, E., Braghiroli, L., Mazzanti, G., Panzironi, C., Grippa, E., \& Silvestrini, B. (1999). Inhibition of protein denaturation by fatty acids, bile salts and other natural substances: A new hypothesis for the mechanism of action of fish oil in rheumatic diseases. Japanese Journal of Pharmacology, 79(1), 89-99. https://doi.org/10.1254/jjp.79.89

Schön, A., Clarkson, B. R., Jaime, M., \& Freire, E. (2017). Temperature stability of proteins: Analysis of irreversible denaturation using isothermal calorimetry. Proteins, 85(11), 2009-2016. https://doi.org/10.1002/prot.25354

Zinellu, A., Sotgia, S., Scanu, B., Forteschi, M., Giordo, R., Cossu, A., Posadino, A. M., Carru, C., \& Pintus, G. (2015). Human Serum Albumin Increases the Stability of Green Tea Catechins in Aqueous Physiological Conditions. PLOS ONE, 10(7), 1-12. https://doi.org/10.1371/journal.pone.0 134690 